\title{
The Gothicization of the Harry Potter Series
}

\author{
By Antonio Sanna \\ Spring 2011 Issue of KINEMA

\begin{abstract}
THE GOTHICIZATION OF THE HARRY POTTER SERIES: THE PROGRESSIVE TRANSPOSITION OF THE GOTHIC INTO THE FILMS
\end{abstract}

\begin{abstract}
In this paper I shall argue that the Harry Potter cinematographic adaptations of J. K. Rowling's novels gradually enacts a transgeneric crossing of the Gothic into the genre of the fantastic. Specifically, by utilizing Robert Mighall's argument that the "Gothic is a process, not an essence; a rhetoric rather than a store of universal symbols", I shall argue that such a transposition is progressively achieved by means of the representation of an imagery clearly recalling Gothic settings, figures and atmospheres, and through the use of a series of thematic preoccupations that are usually present in Gothic texts.
\end{abstract}

According to the critic Robert Mighall, "The Gothic is a process, not an essence; a rhetoric rather than a store of universal symbols; an attitude to the past and the present, not a free floating fantasy world. Epochs, institutions, places, and people are Gothicized, have the Gothic thrust upon them" (xxvi). This paper shall consider the Gothic as a discursive site which absorbs and infiltrates other genres, and shall specifically suggest that the story of Harry Potter becomes Gothicized because of its representation of many settings, characters and themes as evidently Gothic. J. K. Rowling's narrative certainly belongs to the literary genre of the fantastic, a genre which shares some of its thematic concerns and structural characteristics with the Gothic. Indeed, both genres imply the existence of uncanny or supernatural events that transgress the bounds of reality and possibility and that cannot be categorized and explained with real scientific laws (Todorov 25). Specifically, as Rosemary Jackson has argued, "Fantastic literature points to or suggests the basis upon which the cultural order rests, for it opens up, for a brief moment, on to disorder, on to illegality, on to that which [. . . ] is outside dominant value systems" (26-27). Similarly, as several critics have noted, Gothic fiction is an evasive and subversive genre which metaphorically addresses human fears and anxieties through its depiction of supernatural events and nonexistent monsters (Veeder 61, Davenport-Hines 7, Hendershot 1). However, the Gothic genre frequently overindulges on horrific images that are intended to provoke an affective response from the reader/viewer which vary from disgust and abjection to terror and horror.

The Harry Potter novels are characterized by several Gothic elements and preoccupations. Indeed, as some critics have suggested, the texts are permeated by the "themes of evil, darkness, destruction and murder" (Patrick 221) and depict a very dark world that is introduced by the murders of Lily and James Potter and the attempt on the life of Harry by Lord Voldemort (Hook 91). According to Deborah J. Taub, there are "numerous and horrendous instances of violence" (21) throughout the series and death is one of the dominant themes of the narrative, which "moves from wonder, innocence, and comedy to fear, experience, and tragedy" (Behr 263). This has been also recognized by Anne Hiebert Alton, who argues that Rowling's novels incorporate into the narrative a series of different genres such as school story, detective and pulp fiction, mystery and Gothic tales (199). Specifically, the story of Harry repeatedly presents images of haunting (Harry having nightmares about the Dark Lord and a painful telepathic connection with him), destruction (the devastations caused by the attacks of Voldemort's supporters - the Death Eaters) and death (of several among the characters). Other thematic preoccupations frequently present in Gothic texts that characterize the seven-novel saga are: the obsessive return to the shattering moment (Harry's memory of his parents' death), unwanted epiphanies (the young protagonist's involuntary encounters with Voldemort), the invasion of the human body from a hostile or supernatural entity (the Dark Lord's physical and mental possession of Harry - almost suggestive of a sexual abuse of the boy) and the motif of mistaken identity (many characters of the series such as Severus Snape and Sirius Black are considered as villains when actually innocent or vice versa).

The literary texts of Harry Potter are therefore disseminated with Gothic themes and elements that are however further evidenced by the various directors of the cinematographic series. In a certain respect, we could 
argue that the seven films offer an ulterior Gothicization of Rowling's texts through their representations of the story's settings and atmospheric conditions as well as through their visual transpositions of many facts depicted in the novels. Nevertheless, this is achieved progressively and the Gothic imagery increases only as the series develops. Specifically, such a progression could be established by confronting several scenes of the first two films with those included in the following instalments of the series. For example, in Chris Columbus' 2001 Harry Potter and the Philosopher's Stone, both the Muggle (non-magic) metropolis of London and the wizarding high street of Diagon Alley are pictured as very luminous. The first sight of the world of magic by Harry (Daniel Radcliffe) and by the film's viewer includes a very animated world with streets that are full of life and crowded with colourful characters happily chatting to each other.

The following 2002 Harry Potter and the Chamber of Secrets (by Chris Columbus as well) lightly modifies such a perception of Diagon Alley by also introducing the dirty and disreputable parallel street of Nocturn Alley, busy with wizards and witches who look like poor wretched people of a suburb of late-Victorian London. This is however all the more contrasted to the still colourful and luminous Diagon Alley and its lively crowd. In David Yates' 2009 Harry Potter and the Half-Blood Prince, instead, the wizarding high street is represented as the target of the terrorist attack of the Death Eaters during a grey morning or as the nocturnal shelter of malefactors. In Yates' 2010 Harry Potter and the Deathly Hallows: Part 1, the viewer is shown Diagon Alley only during a dark rainy night when crossed by Voldemort's squads enforcing a pure-blood campaign on the wizarding community (a reference to the Gestapo, the Nazi secret police).

Similarly, in both the first and second film, the train to Hogwarts journeys through a green landscape and in very nice weather. The arrival at the school is accompanied by triumphant music (both soundtracks are by John Williams) and Harry's wonder is paralleled to that of the viewer, both of them being introduced to a new and fantastic world. In Alfonso Cuarón's 2004 The Prisoner of Azkaban, instead, the train travels under heavy rain, whereas in Mike Newell's 2005 The Goblet of Fire the journey is conducted through a thick fog. In The Deathly Hallows: Part 1, the serenity of the journey is disturbed by the Death Eaters' boarding of the train and their illegal search for "fugitive" Harry Potter. This is a scene which is not narrated in the novel, but has been added to its cinematographic adaptation, and, in my opinion, it is meant to further emphasize the darker atmosphere of this last film in comparison with the previous ones.

The same argument could be maintained also by examining some of the scenes that are set in open environments. In both The Philosopher's Stone and The Chamber of Secrets, for example, the match of Quidditch occurs during a sunny day. In these sequences, the colours of the towers, of the players' uniforms and of the various houses' banners as well as the green of the wooded hills surrounding the playground are all very bright and vivid. In The Prisoner of Azkaban, however, the match is played in heavy rain and is interrupted by the attack of the Dementors, which almost causes Harry's death because of his fall from the broom. In The Goblet of Fire, the triwizard tournament takes place respectively during a very foggy morning (the fight against the dragon), under the dark and insidious waters of the Black Lake and inside the haunting environment of the maze (a typical set for many Gothic stories). David Yates' 2007 Harry Potter and the Order of the Phoenix associates the various omens of a forthcoming war against the Dark Lord with the rain abundantly pouring during the night and with Voldemort's face materializing in the snow during a storm. Fog also characterizes the weather during the Quidditch training and match in The Half-Blood Prince. Various scenes of the first film that are repeated in the following instalments in the series thus tend to be set in a darker and darker atmosphere which is typical of Gothic novels and horror films.

An example of the gradual Gothicization of the series could be offered through an examination of the musical motifs of the very beginning of all films. Indeed, from The Philosopher's Stone to The Order of the Phoenix, the "Hedwig theme" (initially composed by John Williams and then interpolated by Patrick Doyle and Nicholas Hooper in the fourth and fifth films) accompanies the appearance of both the Warner Bros logo and the titles of the films. A significant change is introduced by Nicholas Hooper at the beginning of The Half-Blood Prince, when the Warner Bros logo is introduced with the "Hedwig theme", but it is juxtaposed to the musical motif of the Death Eaters in the background, as if to suggest the menace Harry has faced at the end of the previous chapter (Bellatrix Le Strange's voice as well can be heard in this precise moment while derisively saying "I killed Sirius Black"). 
The title of the film is then accompanied by some elements of light choir that are reprised throughout the film and specifically linked to the figure of Dumbledore (who is standing by Harry before the appearance of the title). The soundtrack itself is therefore apparently suggestive of dark omens because it juxtaposes the characters of Harry and Dumbledore with the Death Eaters. In The Deathly Hallows: Part 1, there is only a hint of the "Hedwig Theme" during the appearance of the Warner Bros logo. The title of the film - that is, Harry's name - is instead supported by the new Death Eaters leitmotif by Alexandre Desplat, as if to suggest the predominance of the forces of evil over Harry represented throughout the film. This is confirmed also by the fact that, immediately after the title, the viewer is shown Malfoy Mansion and the fluttering spirals of black smoke representing the flight of a Death Eater. In the last film, Harry's name is thus introductory to the reunion of the story's villains rather than to the boy's adventures.

Of course, there is a certain amount of Gothic imagery in the first film of the series as well, such as in the representation of the encounter with the hooded figure drinking unicorn's blood (which reproduces a vampire-like gesture) in the misty Forbidden Forest, or in the depiction of the silent corridor forbidden to the students that is guarded by a three-headed dog (an allusion to Cerberus, guardian of Hell according to Greek and Roman mythology). Gothic elements are introduced also in The Chamber of Secrets, specifically by means of the representation of a scared Harry hearing a voice that comes through the corridors' walls and that speaks a language only he can understand (Parseltongue, snake language), and by means of the inauspicious messages apparently written with blood on the walls of the school. The second film also presents frightening environments such as the lair of the giant spiders in the Forbidden Forest and the chamber of secrets hiding the gigantic and monstrous basilisk and the incarnated malicious memory of Tom Riddle.

Nevertheless, these scenes and environments are definitely not as horrific and frightening as those represented in the following films. We could compare, for instance, the fight between Harry and Professor Quirrell (possessed by the disembodied Voldemort, and interpreted by Ian Hart) near the end of The Philosopher's Stone with the duel between the young wizard and the Dark Lord near the end of The Goblet of Fire. The former occurs in an adorned room completely lit by the fire surrounding the two characters and Harry wins over Quirrell in the brief time of one minute. Harry's fight against the re-incarnated Voldemort (Ralph Fiennes) is set in an abandoned and dark graveyard and is characterized by the extreme violence of Cedric Diggory's (Robert Pattinson) useless death, of the Dark Lord's cruel torture of the young wizard and his intention to, in his words, "destroy" him. The duel between the two opponents is performed in front of the Death Eaters, who are clad in completely black tunics, hooded and masked like the worshippers of a satanic sect. The same argument is true for the epochal and generational fight of Voldemort against Dumbledore (Michael Gambon) in The Order of the Phoenix, involving the use of the four elemental forces and of every meanest and most destructive magical trick both of the adversaries employ to defeat their opponent. This finally causes the devastation of the Ministry of Magic's hall and the laceration of Minister Fudge's gigantic austere picture hanging in front of the offices facing the hall (a metaphor, in my opinion, for Voldemort's defiance of the laws of the wizarding community and for the fact that his powers and influence are stronger than those of Fudge).

We could argue that it is from The Prisoner of Azkaban that the recreation of a Gothic atmosphere is decidedly more evident in the representation of Harry's experiences. This is achieved in one of the film's initial scenes, when the eponymous protagonist first encounters Sirius Black (Gary Oldman) in a suburban street of Little Whinging. In this moment, Harry is carrying his heavy suitcase and stops by a recreation ground. He is completely alone and helpless when the street lamp's light suddenly goes out and the wind unexpectedly blows the leaves and objects around him. Black appears from the bushes on the other side of the road. He is transformed into a famished black dog, but actually looks more similar to a small version of the quadrupedal werewolf represented in films such as John Landis' 1981 An American Werewolf in London or Brett Sullivan's 2003 Ginger Snaps: Unleashed. Black angrily growls at Harry, who is apparently saved only by the prompt arrival of the Nightbus.

The frightening atmosphere represented in this scene is subsequently reprised during Harry's encounter with the Dementor on the train to Hogwarts. According to The Prisoner of Azkaban novel (65-66), Dementors are soulless creatures who drain the happiness of all the people they encounter (both wizards and Muggles) and feed on their good feelings and happy memories. The cinematographic transposition of such creatures by director Cuarón perfectly reproduces Rowling's spectral characterization of them: Dementors are portrayed 


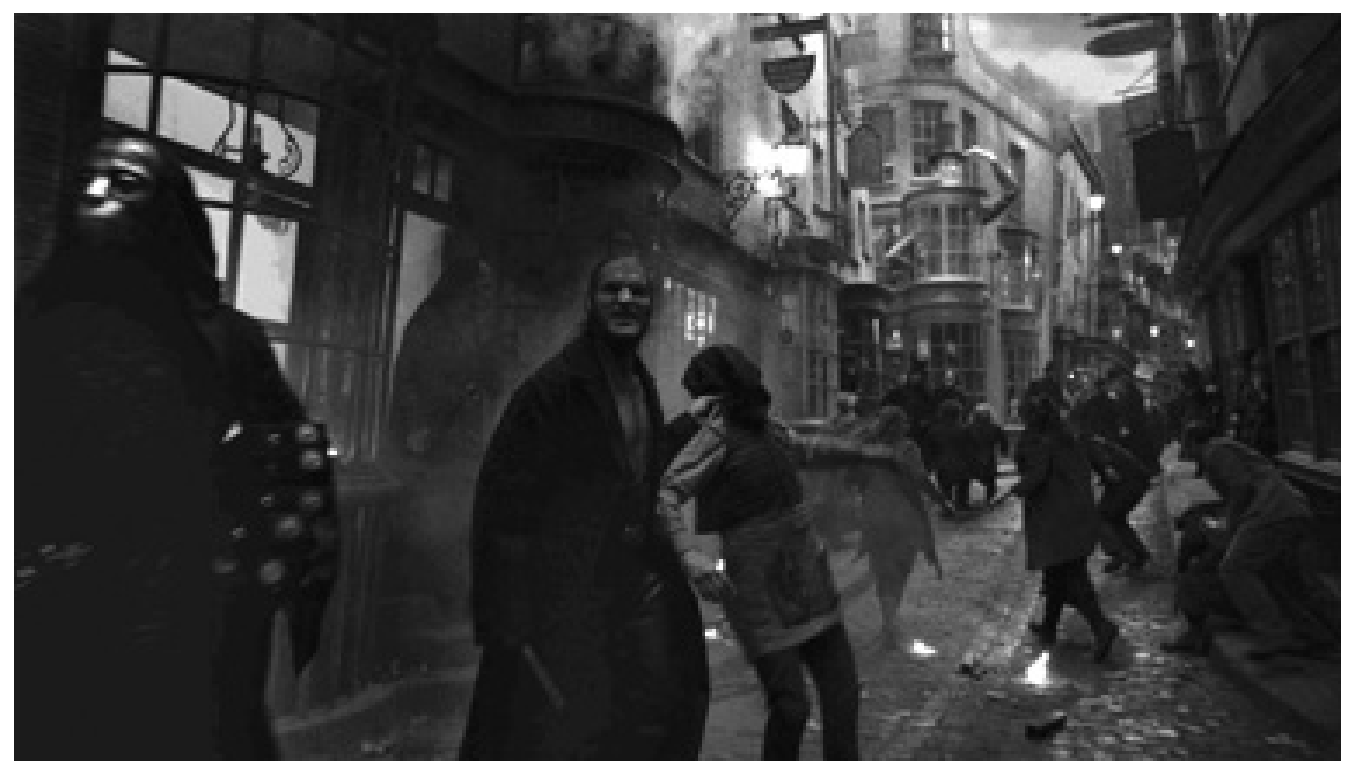

Figure 1: The attack of the Death Eaters in Diagon Alley at the beginning of Harry Potter and The HalfBlood Prince.

as hooded dark beings (very similar to the Dark Knights of The Lord of the Rings trilogy by Peter Jackson), whose faces are perpetually in shadow, and whose floating movements in the air uncannily reproduce the movements of an object under water. Moreover, they are introduced with a properly suspenseful atmosphere which is created by a series of factors: the train abruptly stops with no apparent reason under the heavy rain, the lights go out suddenly and Ron verbally specifies that "there's something moving out there".

The camera then moves towards the train from its outside, thus identifying the spectator's point of view with that of the Dementor coming aboard the train, confirmed by Ron's immediate scared affirmation "I think someone's coming aboard". All of this is further emphasised by the suspenseful music composed by John Williams. The piece "Apparition on the Train" initially contains various orchestral effects (such as tremolo, glissandi and tone clusters) that produce a series of long undeveloped notes intended to provoke a disturbing sound with no clear harmonic referents. As the scene progresses, the music reaches a general effect of breakage: the crescendo and adding up of instruments are visually accompanied by the terror of the characters and (a particular added by Cuarón which is not narrated in the novel) the rain on the train-windows quickly freezing.

The Dementor then appears behind the compartment's door and lifts the handle without even touching it: it moves very slowly and has a definite appearance of the medieval representations of death. After showing a skeletal hand on the compartment's door, it inspects the three children and starts inhaling Harry's good memories in a gesture which actually seems to reproduce the absorption of a person's vital energy or breath (as the little troll does in Lewis Teague's 1985 The Cat's Eye). Professor Lupin (David Thewlis) wakes up and drives the creature away with a spell producing a vivid light: the Dementor slowly recedes in the train's corridor whilst Harry faints and the image fades to complete black. Could we not argue that this scene would be appropriate for a horror film as well, it being intended to represent the terror of the characters and to stimulate the fear of the viewers?

The suspenseful and frightening atmosphere generated in the scene on the train is recalled throughout the rest of the film by means of the repeated shots of the Dementors patrolling the ground around Hogwarts (and withering all of the flowers on their way merely with their physical proximity) and because of the fact that Harry is (presumably) hunted by a dangerous killer even manages to infiltrate the school. This film utilizes Gothic imagery also in its portrayal of a hooded executioner constantly followed by a flock of crows, and of various dark and narrow underground passages. The depiction of these dirty tunnels is certainly indebted to the description of subterranean tunnels present in Gothic novels such as Matthew Lewis's 1796 
The Monk and Bram Stoker's 1897 Dracula. Moreover, these passages lead to the Shrieking Shack, which is described by the character of Hermione (Emma Watson) as "the most haunted building" in Britain and therefore epitomizes the dusty haunted mansion depicted in several Victorian ghost stories such as Mrs. J. H. Riddell's 1882 "Walnut-Tree House", Br am Stoker's 1891"The Judge's House" and Ella d'Arci's 1896 "The Villa Lucienne". The transformation of Professor Lupin into a werewolf is inescapably Gothic as well, with the man's eyes assuming an unnatural shape and colour as soon as they glance at the full moon, the scars on his face mutating into an elongated jaw, the body painfully distorting its shape and size, and his immediate abandonment of all traces of humanity, especially when chasing Harry and Hermione on all-fours in the forest.

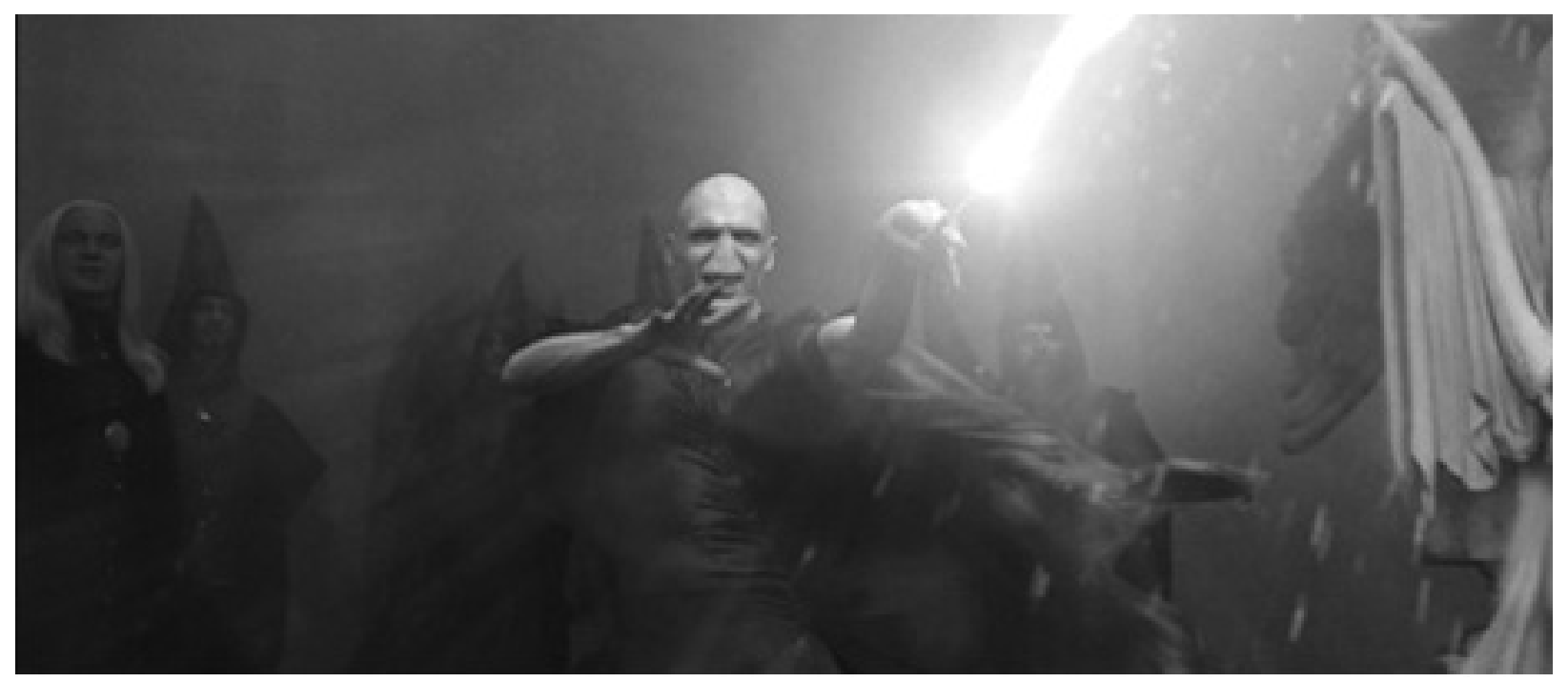

Figure 2: Voldemort (Ralph Fiennes) is surrounded by the Death Eaters while duelling against Harry near the end of Harry Potter and the Goblet of Fire (copyright Warrner Bros).

Such a Gothic atmosphere and such Gothic settings are reprised in the fourth film, The Goblet of Fire, which actually begins with the close up of a series of skulls carved on a grave. The camera then follows Nagini (Voldemort's huge snake and most cruel servant) while crawling towards a monumental tomb surmounted by a statue of winged death, behind which the title of the film finally appears, emerging from a nocturnal and cloudy sky. Gothic imagery is utilized also in the scene of the Death Eaters' attack at the Quidditch World Cup, which leaves the wizards' camp and its numerous tents totally burnt and destroyed as if after a violent Medieval battle. The Dark Mark of Voldemort created in the sky over the deserted camp-battle field could be seen as influenced by Gothic imagery as well, with its huge human skull vomiting a snake that hovers in the clouds.

In the Goblet of Fire, there is much emphasis on the architecture of Hogwarts, and, specifically, on some of the Gothic components of it. Indeed, the viewer is first shown a serpent-like gargoyle on a tower that pours out heavy rain during the night. The castle - itself the proper setting for horror stories since Horace Walpole's 1764 The Castle of Otranto - is then repeatedly shown through shots that emphasise the sense of height which is characteristic of Gothic cathedrals (especially during Harry's fight against the dragon). In this film, many other elements of the story are Gothicized: the mermaids of the Black Lake are not pictured as the very attractive creatures of the Greek myth, but as small amphibious beings with cruel facial expressions. In particular, Voldemort's appearance is extremely Gothic because of his flat nose, his eerie complexion, very livid skin and his long pointed nails. The very re-birth of the Dark Lord could be seen as a satanic rite with its dark ritual involving flesh, bones and blood, whereas the villain's physical form during the process of transformation into a sort of adult posthuman subject could remind the viewer of the ominous and lethal extraterrestrial creature of Ridley Scott's 1979 Alien.

In The Order of the Phoenix Gothic elements are introduced quite early in the film and are firstly extended 
to the Muggle world with the Dementors' totally-unexpected attack in Little Whinging. Indeed, in the brief time of a few seconds, a hot and sunny day uncannily becomes stormy, with black clouds literally following Harry and his cousin Dudley Dursley (Harry Melling) while running home. When crossing a pedestrian tunnel, the two boys then notice that the water around them is freezing. This is a very brief warning for both Harry and the viewer, who do not have the time to realize what is happening. Unexpectedly, a Dementor appears from a dark corner of the tunnel's ceiling and savagely grabs Harry by the throat (it is the first time in the series that Dementors physically assault a human being).

The attack is sudden and violent and all the more frightening because it involves the Muggle boy too: this disturbs the "Muggle" viewers' perception that non-magic people are safe in the fictional world created by Rowling. Secondly, before Harry arrives at school, the spectator is introduced to the Thestrals, black winged horses with foggy eyes and skeletal bodies. According to the story, Thestrals can appear only to those who have seen death and, in my opinion, they thus recall the pale fourth horse of the Apocalypse in the Bible (Rev. 6:8). Moreover, an extremely Gothic detail has been added to this film through the representation of the Death Eaters' ability to fly when haunting Harry and his friends in the labyrinthine corridors of the Ministry of Magic. According to The Deathly Hallows novel (70), Voldemort is the only wizard who can fly. By showing Death Eaters as black whirls of dense smoke and, specifically, by setting them in contrast to the good Aurors and members of the Order of the Phoenix (who transform into white and luminous smoke), director Yates further emphasises the difference between the two opposite orders and the respective inner natures of the characters belonging to them.

In The Half-Blood Prince, both the Warner Bros logo and the film's title appear in the middle of a stormy and rumbling sky. The story begins with the attack of the Death Eaters in Diagon Alley, the kidnapping of the wand-maker Olivander and the collapse of the Millennium Bridge in London. I would suggest that, by choosing to clearly show London's central and most crowded streets as well as by converting the destruction of an anonymous bridge recounted in Rowling's novel (The Half-Blood Prince 9) into the collapse of the Millennium Bridge (one of the most visited sites of the capital), these acts are precisely intended to look like terrorist actions. They create a climate of fear for the characters and viewers of the story from the beginning of the film and are a specific reminder of the terrorist attacks London suffered on $5^{\text {th }}$ July 2005 . In this way, the terror of the story's characters is paralleled to that of the viewers for the corresponding horrific facts occurring in the "real" world.

The story then proceeds alternating serene moments (such as Harry's flirting with a Muggle girl in a Café or his encounter with his friends at the Weasleys' house) to much more preoccupying and gloomy scenes (the Death Eaters' visit to Severus Snape - Alan Rickman - or Draco Malfoy's - Tom Felton - malicious deals in Nocturn Alley). Thematically, the whole narrative of The Half-Blood Prince alternates between moments of serenity and even some comic scenes (such as the flirtations among the students or Ron's - Rupert Grint - delirious reveries under the influence of a love potion) and sequences depicting the secret wrongdoings of the story's villains (the several attempts on the life of Headmaster Dumbledore and Draco's anguished wandering through the castle during the night). Specifically, it should be noted that a grey atmosphere is often imposed on many scenes of The Half-Blood Prince. This effect is partly achieved by means of almost all of the external scenes of the film being acted in a rainy, snowy and very cloudy weather or during the night, and is completely realized through the imposition of a blue/grey filter on the images of Dumbledore's first memory of Tom Riddle (Hero Fiennes-Tiffin). This specific scene shows many spirals of black smoke transforming into the buildings of 1950s London, whereas the people on the street actually look like ghosts emanating vaporous wakes. The orphanage has a very spectral and sinister look, which is emphasised by the fact that the borders of the images are often out of focus and that young Tom Riddle's voice produces a very uncanny effect because of its sibilant echo while he describes his power to talk to snakes.

Particularly, it is interesting to analyse the scene of the attack of the Death Eater Bellatrix Le Strange (Helena Bonham Carter, properly attired in a Gothic fashion that includes tight bust, black shirt with long sleeves and an embroidered skirt) and the werewolf Finrir Greyback (Dave Legeno) at the Weasleys' house. This scene has been purposely created for the film and is not narrated in the novel at all. While celebrating Christmas and precisely in the romantic moment in which he is about to kiss Ginny Weasly (Bonnie Wright) for the first time, Harry sees Bellatrix appearing close to the flames that suddenly flare up around the house. He immediately follows the malevolent witch through the thick canes in order to avenge the murder 
of his godfather Sirius Black. Ginny runs after Harry and soon gets lost among the canes of the pond. She suddenly realizes that someone is close to her and calls for Harry with a trembling voice. However, it is the werewolf Greyback who emerges from the darkness with a greedy smile and is ready to assault her when Harry intervenes and drives him away with a spell.

The two young wizards are then attacked by both Greyback and Bellatrix, who remain however hidden among the canes all the time while circling them like predatory animals do with their prey. Could we not compare this scene to those sequences of a horror film in which the good characters are stalked by a villain or monster in a dark and confusing setting, especially to those conventional scenes in which the girl is (sexually) menaced by the villain and then rescued by the male character(s)? Indeed, this is a typical plot of many horror films from the very beginning and throughout the history of the genre, such as in the cases of Rupert Julian's 1925 The Phantom of the Opera, Jack Arnold's 1954 Creature from the Black Lagoon, Steve Miner's 1981 Friday the 13 $3^{\text {th }}$ : Part 2 and Stephen Sommers' 1999 The Mummy, to merely name a few.

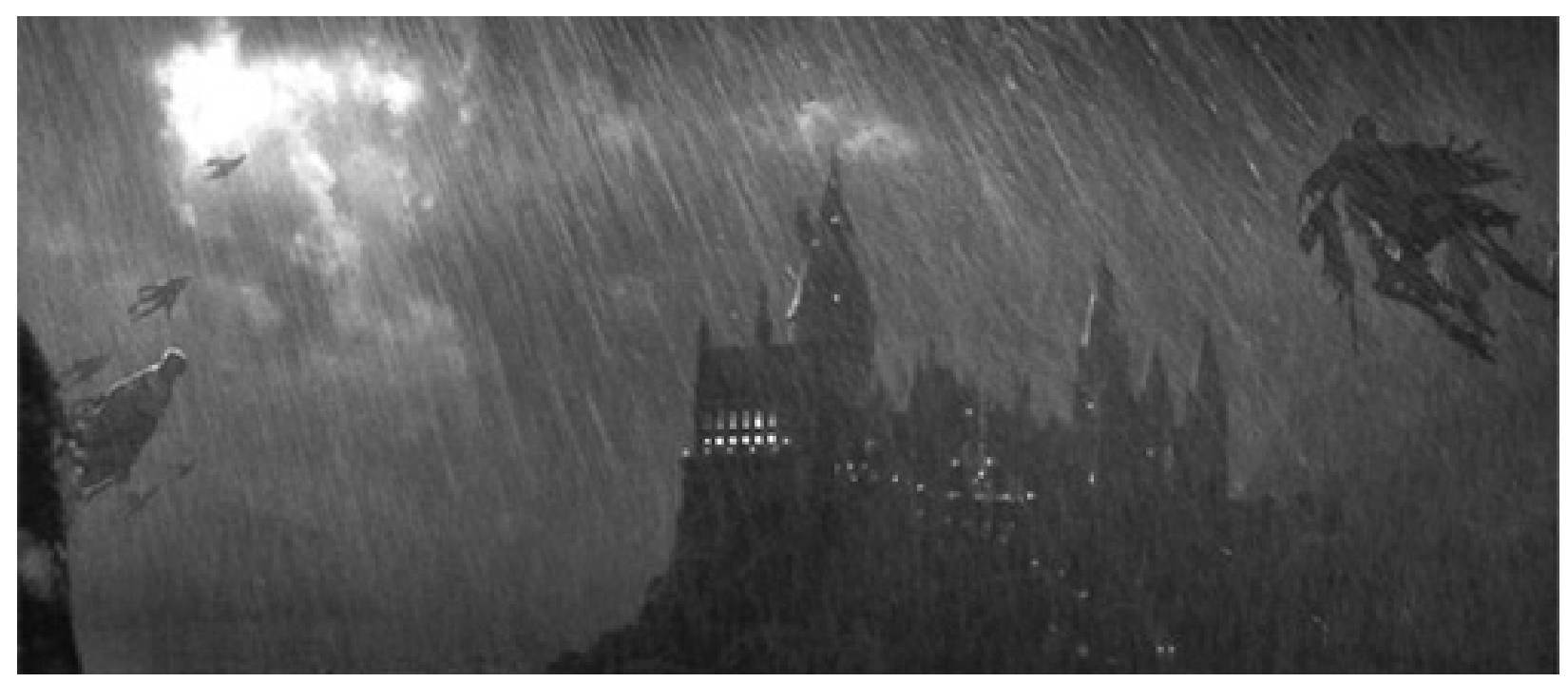

Figure 3: Dementors patrolling the area around Hogwarts Castle in Harry Potter and the Prisoner of Azkaban (copyright Warner Bros).

Similarly, the scene set in the cave near the end of the film definitely appears to be influenced by a horror film. The underground environment is recreated in a very realistic way, with the voices of the characters gloomily rumbling in the void and obscurity surrounding them. Most importantly, the army of unstoppable and mortal Inferi unexpectedly emerging from the subterranean lake and attempting to drown Harry can be easily compared to a group of zombies attempting to reach and eat alive their victims in films such as George A. Romero's 1968 Night of the Living Dead or Paul W. S. Anderson's 2002 Resident Evil. This sequence of The Half-Blood Prince could be considered as very similar also to some scenes of Neil Marshall's The Descent and Bruce Hunt's The Cave. In both of these 2005 films a group of speleologists is attacked and massacred by some livid creatures indigenous to the underground environment. These are eager for human flesh and use subterranean lakes and pools to hide before assaulting the humans. Moreover, the characters of The Cave and The Descent physically fight against such monsters, precisely as Harry does with the Inferi after unsuccessfully attempting different spells to repel them.

Finally, the Death Eaters' infiltration into Hogwarts, the murder of Dumbledore, the revelation that Professor Snape is an agent of Voldemort and the appearance of the Dark Mark in the sky above the school (all representing the penetration of evil into the ultimate safe resilience of goodness) suggest a very gloomy future for the main characters of the narrative. This is indeed realized in the following film in the series with the fall of the Ministry, its infiltration by the Dark Lord's agents and the substantial bounty set for the capture of Harry Potter. Once Voldemort is able to manoeuvre the Ministry and transform it into a sort of fascist regime, the young wizard, the "Chosen One" becomes the "Undesirable Number One". The 
boy's moving image comes to be portrayed on the wizarding papers and in the posters hanging on the walls of Diagon Alley, precisely as was in the case of Sirius Black, Bellatrix Le Strange and Finrir Greyback respectively in the third, fifth and sixth films. A parallel is thus established through such posters between the wrongly-accused Potter and Black, who are instead associated with the real and most dangerous criminals Bellatrix and Greyback.

The Deathly Hallows: Part 1 is certainly the darkest film in the series: it begins with Harry, Hermione and Ron abandoning their homes for the dangerous search and destruction of the Horcruxes. The second scene of the film introduces a Gothic atmosphere by presenting Professor Burbage (Carolyn Pickles) as suspended over the table reuniting Voldemort and all of his most faithful servants in the aristocratic living room of Malfoy Mansion. Burbage is overturned and her face full of scars and blood is wet with tears (an image which partly reminded me of young girl Regan - Linda Blair - in William Friedkin's 1973 The Exorcist). She supplicates for her life to be spared but Voldemort savagely kills her. After Burbage's body noisily falls on the table, the camera cuts to a close-up of her corpse's face while her last tear drop is dripping down the bruised cheek. Voldemort then offers her dead body as a meal to Nagini, who climbs on the table and moves towards the camera. In this moment, the viewer is given the perspective of the victim's corpse, of a meal for the snake whose jaws' sudden closing on the camera abruptly ends the sequence. The very second scene of the film thus not only present a brutal murder, but also the Death Eaters' terror of their own leader and the incapacity of Snape to save his friend Burbage before the forces of evil.

Such a tragic atmosphere is subsequently maintained by means of the deaths of the owl Hedwig and the Auror Mad-Eye Moody (Brendan Gleeson) during the battle over the clouds. It is all the more reinforced by the tribunal scene set in the basement of the Ministry of Magic, with the inquisitorial brutality of the process enforced by Dolores Umbridge (Imelda Staunton) and the presence of the Dementors menacingly standing above the accused and immediately intervening to stop Harry when escaping.

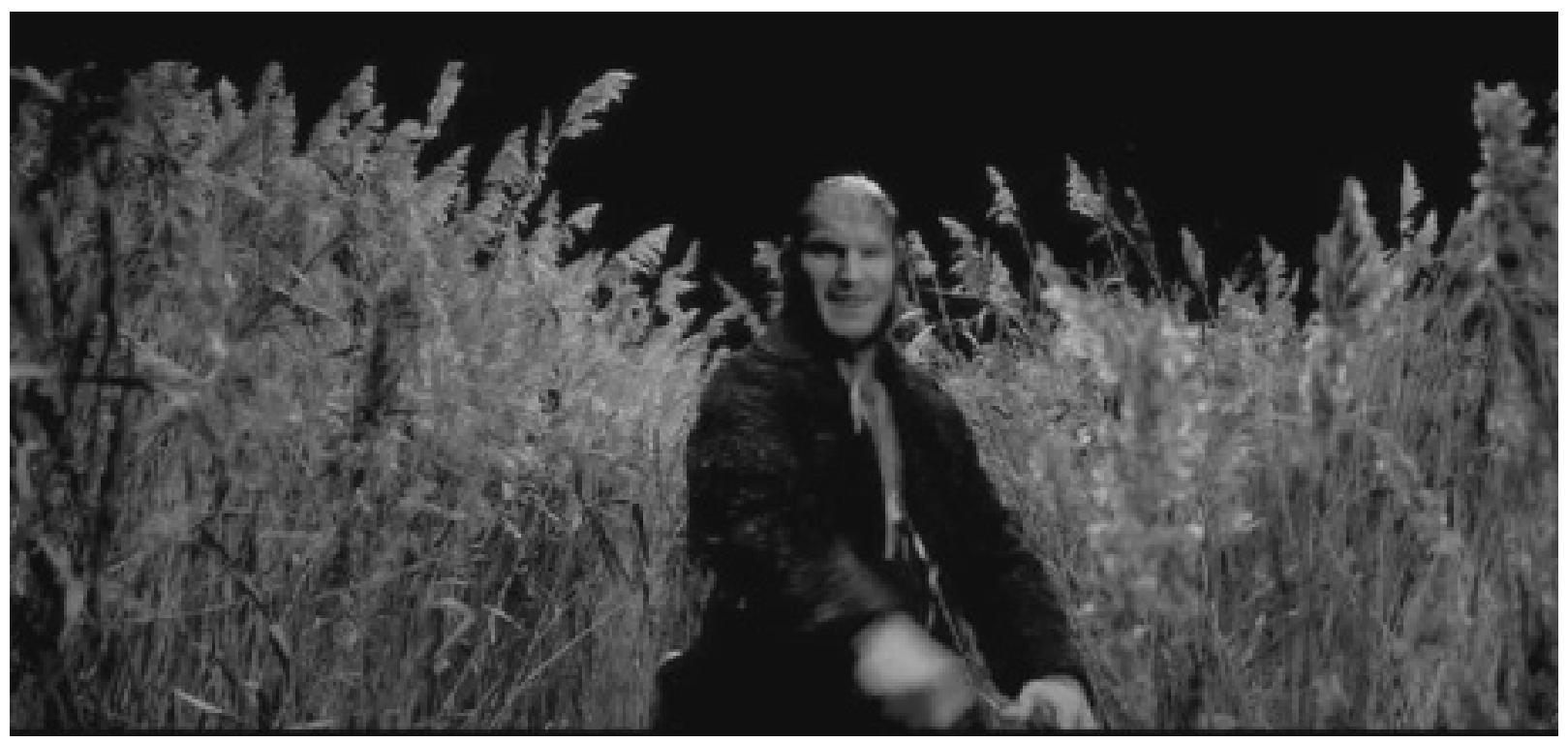

Figure 4: Werewolf Fenrir Greyback (Dave Legeno) emerging from the canes in Harry Potter and The Half-Blood Prince (copyright Warner Bros).

Particularly, it is inescapable to notice that the scene set in historian Bathilda Bashot's home in Godric's Hollow is indebted to the conventions of horror films. Indeed, Harry and Hermione follow the old woman (Hazel Douglas) in her old and apparently abandoned house. There are no lights inside except for the feeble candle lit by Bathilda. This forces the viewer to distinguish only very few particulars of the place's furniture and structure. The old woman never replies to Harry's questions in front of Hermione and invites the young boy to follow her upstairs. She then whispers some words to him that cannot be actually understood by the viewer. 
This is because she speaks Parseltongue, an indication for the spectator that something is wrong, but not for Harry, who cannot distinguish the difference between English and snake language. In the meantime, Hermione furtively peeps around the house until she discovers the real dead body of the old woman. The image quickly cuts back to Bathilda, who starts suffering convulsions and sinks to the ground while Nagini suddenly appears from her empty clothing. The snake immediately attacks Harry, who barely manages to stand up in the dark and very disordered environment. The scene is very confusing with the snake assaulting Harry with sudden darts. This is all the more emphasised by Alexandre Desplat's soundtrack which, during the children's exploration of the abandoned house, presents a series of still notes expressing a sense of immobility.

The piece (called "Bathilda Bagshot") produces a series of static musical effects that contribute to the creation of a suspenseful atmosphere. This is however abruptly interrupted by the very strong crescendos and the production of the strings' sudden, obstinate and marked distortions that accompany the violent fight of Harry against Nagini, increase the menacing tension of the scene and accelerate its rhythm. In this precise moment, Desplat's piece is composed of many percussion instruments that are mixed with the strings performing a mighty scale in crescendo. Hermione's providential intervention and the momentary defeat of Nagini are marked by the sudden interruption of such a crescendo, which, however, leaves a strident background that does not stop the tension until the snake is hit again by Hermione's second spell and the two wizards escape by jumping out of the room's window.

It is interesting to note that the very ending of all of the Harry Potter films signals a progressive passage from a happy resolution to a sad conclusion burdened with black expectations for the future. Whereas the first two films present the defeat of Voldemort (respectively, with the death of Quirrell and the destruction of Tom Riddle's diary), from the third film onwards the events becomes less and less serene. Indeed, although having managed to rescue the hippogriff Buckbeack and having discovered the truth on Sirius Black's innocence, in The Prisoner of Azkaban the flight of the Dark Lord's servant Wormtail (Timothy Spall) offers a bitter ending for the viewer because of the story's villain not being "punished" at the end of the story.

The Goblet of Fire and The Order of the Phoenix both have very sad endings, respectively with the murder of Cedrig Diggory and the return of the Dark Lord, and with the latter's further escape, his nefarious promise to Harry ("You will lose everything") and the murder of Harry's godfather Sirius. Even worse is the ending of The Half-Blood Prince, with the death of Dumbledore, and therefore the loss of Harry's only paternal figure as well as of the only character with full knowledge of the means to defeat Voldemort. The Deathly Hallows Pt. 1 concludes with the unexpected death of Dobby, the tender house-elf who saves Harry from Malfoy family, and with the Dark Lord's mocking plunder of Dumbledore's tomb and his acquisition of the elder wand, the most powerful known to exist in Rowling's fictional world.

Robert Mighall's argument that the Gothic is a process and rhetoric infiltrating and contaminating other genres can therefore be properly applied to the Harry Potter films, which often utilize Gothic imagery, tropes and figures. Specifically, by confronting several scenes of the first two films with those more frightening and suspenseful sequences present in the following instalments of the series, we can argue that the cinematographic adaptations of Rowling's novels are endowed with a Gothic thrust, which is progressively evidenced by the various directors as the series develops. This is achieved by means of the directors' representations of many settings and of the weather conditions as well as by their addition of scenes not narrated in the novels which rely on a series of conventions typical of Gothic novels and horror films. In the Harry Potter films, the Gothic is thus re-instated and transposed into the medium of the fantastic.

\section{References}

\section{Works Cited}

Alton, Anne Hiebert. "Playing the Genre Game: Generic Fusions of the Harry Potter Series." Critical Perspectives on Harry Potter. Ed. Elizabeth E. Heilman. 2nd ed. London: Routledge,2009. 199-223.

Behr, Kate. "Philosopher's Stone to Resurrection Stone: Narrative Transformations and Intersecting cultures across the Harry Potter Series." Critical Perspectives on Harry Potter. 2nd ed. Ed. 


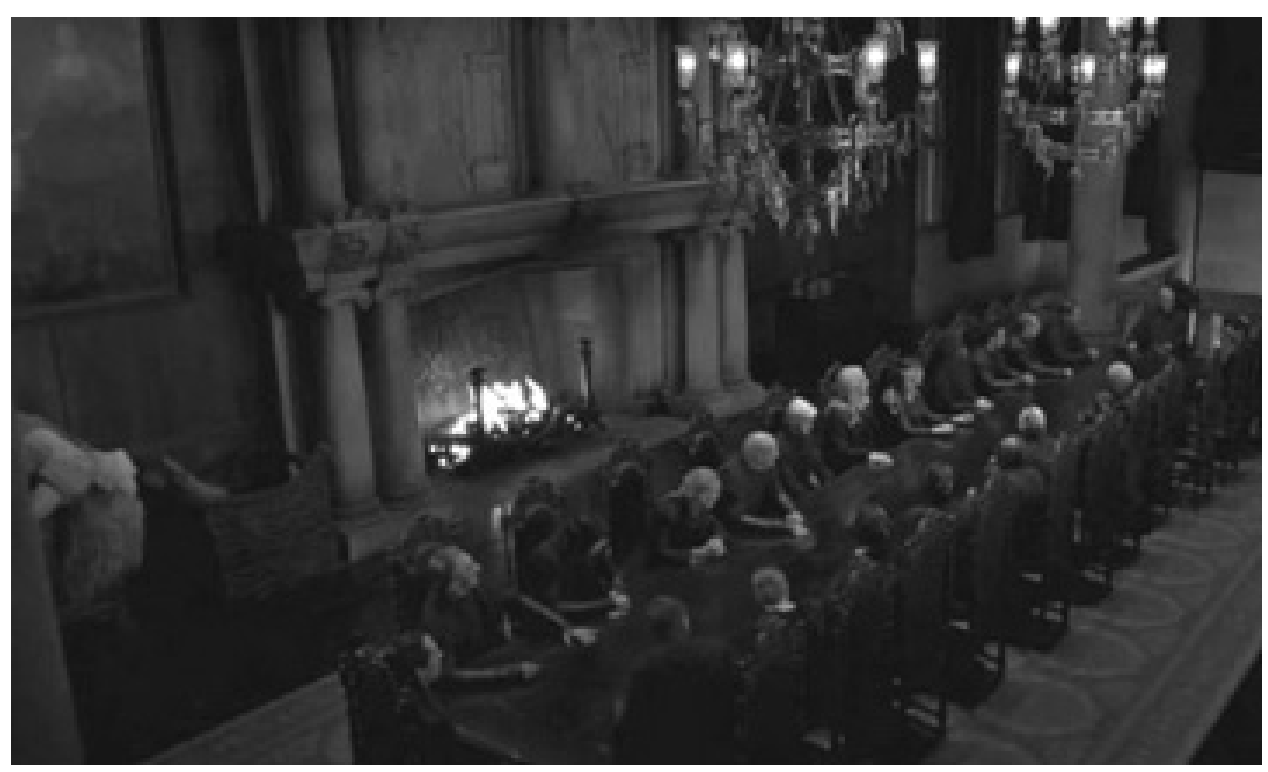

Figure 5: Voldemort and the Death Eaters reunited in Malfoy Mansion near the beginning of Harry Potter and the Deathly Hallows: Part 1. On the left, Professor Burbage is overturned and suspended in the air (copyright Warner Bros).

Elizabeth E. Heilman. London: Routledge, 2009. 257-71.

Bousquet, Marc. "Harry Potter, the War against Evil, and the Melodramatization of Public Culture." Critical Perspectives on Harry Potter. 2nd ed. Ed. Elizabeth E. Heilman. London: Routledge, 2009. 177-95.

Cornwell, Neil. The Literary Fantastic: From Gothic to Postmodernism. London: Harvester Wheatsheaf, 1990.

d'Arci, Ella. "The Villa Lucienne." The Virago Book of Victorian Ghost Stories. Ed. Richard Dalby. London: Virago Press, 1992. 301-08.

Davenport-Hines, Richard.. Gothic: 400 Years of Excess, Horror, Evil and Ruin. London: Fourth Estate, 1998.

Hendershot, Cindy. The Animal Within: Masculinity and the Gothic. Ann Arbor, MI: U of Michigan Press, 2001.

Hook, Misty. "What Harry and Fawkes Have in Common." The Psychology of Harry Potter: An Unauthorized Examination of the Boy Who Lived. Ed. Neil Mulholland. Dallas, TX: Benbella Books, 2006. 91-104.

Lewis, Matthew. The Monk. 1796. London: Wordsworth Editions, 2009.

Mighall, Robert. A Geography of Victorian Gothic Fiction: Mapping History's Nightmares. Oxford: OUP, 1999.

Patrick, Christopher J. and Sarah K. Patrick, "Exploring the Dark Side: Harry Potter and the Psychology of Evil." The Psychology of Harry Potter: An Unauthorized Examination of the Boy Who Lived. 
Ed. Neil Mulholland. Dallas, TX: Benbella Books, 2006. 221-32.

Riddell, J. H. "Walnut-Tree House." The Collected Stories of Mrs. J. H. Riddell. Ed. E. F. Bleiler. New York: Dover Publications, 1977. 148-72.

Rowling, J. K. Harry Potter and the Prisoner of Azkaban. London: Bloomsbury, 1999.

. Harry Potter and the Half-Blood Prince. London: Bloomsbury, 2005.

. Harry Potter and the Deathly Hallows. London: Bloomsbury, 2007.

Stoker, Bram. Dracula. 1897. London: Penguin Books, 1994.

. "The Judge's House." Best Ghost and Horror Stories. Ed. Richard Dalby, Stefan Dziemianowicz and S. T. Joshi. Mineola, NY: Dover Publications, 1997. 113-31.

Taub, Deborah J. and Heather L. Servaty-Seib, "Controversial Content: Is Harry Potter Harmful to Children?" Critical Perspectives on Harry Potter. 2nd ed. Ed. Elizabeth E. Heilman. London: Routledge, 2009. 13-32.

Todorov, Tzvetan. The Fantastic: A Structural Approach to a Literary Genre. 1970. Trans. Richard Howard. Ithaca, NY: Cornell UP, 1980.

Veeder, William. "The Nurture of the Gothic; or, How Can a Text be both Popular and Subversive?"Spectral Readings: Towards a Gothic Geography. Ed. Glennis Byron and David Punter. London: Macmillan, 1999. 54-70.

Walpole, Horace. The Castle of Otranto: A Gothic Story. 1764. Oxford: Oxford UP, 2008.

Filmography

Alien. Dir. Ridley Scott. Twentieth Century Fox, 1979.

An American Werewolf in London. Dir. John Landis. Universal, 1981.

The Cat's Eye. Dir. Lewis Teague. Metro-Goldwyn-Mayer, 1985.

The Cave. Dir. Bruce Hunt. Screen Gems, 2005.

Creature from the Black Lagoon. Dir. Jack Arnold. Universal, 1954.

The Descent. Dir. Neil Marshall. Lionsgate, 2005.

The Exorcist. Dir. William Friedkin. Warner Bros, 1973.

Friday the 13th: Part 2. Dir. Steve Miner. Paramount Pictures, 1981.

Ginger Snaps: Unleashed. Dir. Brett Sullivan. Lions Gate Films, 2003.

Harry Potter and the Philosopher's Stone. Dir. Chris Columbus. Warner Bros, 2001.

Harry Potter and the Chamber of Secrets. Dir. Chris Columbus. Warner Bros, 2002. 
Harry Potter and the Prisoner of Azkaban. Dir. Alfonso Cuarón. Warner Bros, 2004.

Harry Potter and The Goblet of Fire. Dir. Mike Newell. Warner Bros, 2005.

Harry Potter and the Order of the Phoenix. Dir. David Yates. Warner Bros, 2007.

Harry Potter and the Half-Blood Prince. Dir. David Yates. Warner Bros, 2009.

Harry Potter and the Deathly Hallows: Part 1. Dir. David Yates. Warner Bros, 2010.

The Lord of the Rings: The Fellowship of the Ring. Dir. Peter Jackson. New Line Cinema, 2001.

The Lord of the Rings: The Two Towers. Dir. Peter Jackson. New Line Cinema, 2002.

The Lord of the Rings: The Return of the King. Dir. Peter Jackson. New Line Cinema, 2003.

The Mummy. Dir. Stephen Sommers. Universal, 1999.

Night of the Living Dead. Dir. George A. Romero. The Walter Reade Organization, 1968.

The Phantom of the Opera. Dir. Rupert Julian. Universal, 1925.

Resident Evil. Dir. Paul W.S. Anderson. Constantin Film, 2002.

Musical Recordings

Desplat, Alexandre. Harry Potter and the Deathly Hallows: Part 1. Water Tower Music, 2010.

Doyle, Patrick. Harry Potter and the Goblet of Fire. Warner/Sunset, 2005.

Hooper, Nicholas. Harry Potter and The Order of the Phoenix. Warner/Sunset, 2007.

Harry Potter and the Half-Blood Prince. New Line Records, 2009. Williams, John. Harry Potter and the Philosopher's Stone. Atlantic Records, 2001.

2002.

Harry Potter and the Chamber of Secrets. Cond. William Ross. Atlantic Records, . Harry Potter and the Prisoner of Azkaban. Warner/Sunset, 2004.

\section{Author Information}

Antonio SANNA received his $\mathrm{PhD}$ at the University of Westminster in London. His publications include articles on James's "The Turn of the Screw", Stoker's Dracula, H. G. Wells's The Island of Dr. Moreau, Victorian ghost stories and Beowulf; the Alien quadrilogy, Ridley Scott's Hannibal and the Harry Potter films. He has contributed to The Dictionary of Literary Characters. 